\title{
AMINO ACID SEQUENCE OF CARBOXYPEPTIDASE Y. I. PEPTIDES FROM CLEAVAGE WITH CYANOGEN BROMIDE
}

\author{
by \\ BRIAN M. MARTIN ${ }^{1)}$, IB SVENDSEN, THAMMAIAH VISWANATHA ${ }^{2)}$ \\ and JACK T. JOHANSEN ${ }^{3)}$ \\ Carlsberg Laboratory, Department of Chemistry, \\ Gamle Carlsberg Vej 10, DK-2500 Copenhagen Valby \\ 1) Present address: Max-Planck Institut für Ernährungsphysiologie \\ Rheinlanddam 201, D-4600 Dortmund 1, W. Germany \\ 2) Present address: University of Waterloo, Department of Chemistry, \\ Waterloo, Ontario, Canada N2L 3GI \\ 3) Carlsberg Biotechnology Ltd. A/S \\ Tagensvej 16, DK-2200 Copenhagen $\mathrm{N}$
}

Keywords: Carboxypeptidase $\mathrm{Y}$, amino acid sequence, yeast

The partial amino acid sequence of carboxypeptidase $Y$ from Sacharomyces cerevisiae has been determined by automated Edman degradation. Peptides were obtained by cyanogen bromide cleavage of the native enzyme and of the carboxymethyl-diisopropylphosphoryl enzyme and by further fragmentation of selected cyanogen bromide peptides after reduction and alkylation, by trypsin, A. mellea protease and S.aureus V8 protease. Together with the peptides presented in the following paper (26) 416 of approximately 430 amino acid residues can be placed in their sequential order.

\section{INTRODUCTION}

Carboxypeptidase Y (E.C.3.4.12.1) is an intracellular exopeptidase isolated from yeast (4), which is a glycoprotein $(10,17)$ composed of a single polypeptide chain with a molecular weight of approximately $63,000(10,17)$. CPD-Y is inactivated by diisopropylphosphorofluoridate (10) and possesses a single sulphydryl residue which upon treatment with mercurials or iodoacetic acid alters the catalytic properties of

\footnotetext{
Abbreviations: $\mathrm{CM}=$ carboxymethyl; $\mathrm{CPD}-\mathrm{Y}=$ carboxypeptidase $\mathrm{Y} ; \mathrm{DFP}=$ diisopropylphosphorofluoridate; DIP = diisopropylphosphoryl; HPLC = high performance liquid chromatography; Polybrene $=1,5$ dimethyl-1,5-diazaundecamethylene polymethobromide; PTH = phenylthiohydantoin; Ser = serine residue that reacted with DFP; THEED $=\mathrm{N}, \mathrm{N}, \mathrm{N}^{\prime}, \mathrm{N}^{\prime}$-tetrakis(2-hydroxyethyl)ethylene diamine; $\mathrm{TLC}=$ thin layer chromatography.
} 
the enzyme $(11,15)$. The carbohydrate content of the enzyme varies depending on the source of yeast from which it is purified (15).

The utility of carboxypeptidase $\mathrm{Y}$ both for synthesis and degradation of peptides and proteins from their carboxy-terminal is well documented $(10,31)$.

The differences between carboxypeptidase $Y$ with its active site serine and the metallocarboxypeptidases $A$ and $B$ alone provide sufficient reason for attempting to determine the amino acid sequence. Other groups have previously reported $\mathrm{N}$ - and $\mathrm{C}$-terminal sequences along with the sequence of the active site serine peptide $(10,11,17)$. However, the rest of the sequence remained to be determined.

We report in the present paper the $\mathrm{N}$-terminal sequence of CPD-Y and of the peptides obtained by cleavage with cyanogen bromide.

The peptides obtained were purified by gel chromatography initially without reduction of the disulphide bridges and finally after reduction with dithiothreitol and alkylation with 4-vinylpyridine. The peptide fragments generated by cyanogen bromide cleavage were in several instances the result of peptide bond splitting after tryptophan (3). Amino acid compositions and sequences of the major peptide fragments are presented.

\section{MATERIALS AND METHODS \\ 2.1. Materials}

Carboxypeptidase $\mathrm{Y}$ was isolated as previously described (15). Trypsin treated with diphenylcarbamylchloride, chymotrypsin $(3 \times$ crystallized), dithiothreitol, and iodoacetic acid were purchased from Sigma Chemical Company, St. Louis, Mo., U.S.A. S. aureus (strain V8) protease was a product of Miles Laboratories Ltd., Stokes Poges, England. Cyanogen bromide, 4-vinylpyridine and UV solvent grade ethyl acetate (used in the sequencer) were from Merck Chemicals, Darmstadt, West Germany. ${ }^{14} \mathrm{C}$ iodoacetic acid and ${ }^{3} \mathrm{H}$-diisopropyl phosphorofluoridate were obtained from The Radiochemical Centre, Amersham, England, and were used after appropriate dilution with the unlabelled analytical grade reagents. A.mellea protease was a gift from VIBEKe Barkholt-Pedersen, Insti- tute of Molecular Genetics, University of Copenhagen.

Biogel P60, P30 and P6 were purchased from Biorad, Richmond, Ca., U.S.A. and Sephadex G25 and ConA-Sepharose were from Pharmacia, Uppsala, Sweden.

Reagents and solvents for the sequencer were obtained through Pierce Europe, Rotterdam, Holland, with the exception of THEED which was from ICN-K\&K Laboratories, Inc. Plainview, N.Y., U.S.A. and ethyl acetate which was from Merck.

All other chemicals were analytical grade. Distilled deionized water was used throughout.

\subsection{Methods}

\subsubsection{Labelling of active-site serine and alkyla- tion of single sulphydryl residue}

Carboxypeptidase Y (300 mg, approx. 5 umoles) was initially inactivated with ${ }^{3} \mathrm{H}$ diisopropyl phosphorofluoridate at $\mathrm{pH} 6.8$ (10 $\mu$ moles ${ }^{3} \mathrm{H}$-DFP diluted to $20 \mu \mathrm{Ci}$. $\mu$ mole $^{-1}$ with cold DFP) for 30 minutes, followed by addition of a further 100 umoles DFP (unlabelled). Twenty minutes after the second addition of DFP, the solution was made $6 \mathrm{~m}$ in guanidine hydrochloride and the $\mathrm{pH}$ adjusted to 8.2. In order to locate the single sulphydryl residue in CPD-Y, ${ }^{14} \mathrm{C}$-iodoacetic acid $(20 \mu$ moles at specific activity of $20 \mu \mathrm{Ci} \cdot \mu \mathrm{mole}^{-1}$ after dilution) was added, followed by a further $100 \mu$ moles $\mathrm{ICH}_{2} \mathrm{COOH}$ after 10 minutes. The alkylation was conducted (in a sealed brown bottle to avoid side reactions) for a total of 25 minutes. The mono-alkylated DIP-enzyme was separated from reactants and salts by chromatography on Biogel P6 $(2 \times 50 \mathrm{~cm})$ using water as eluant. The protein containing fractions were pooled and lyophilized prior to cyanogen bromide cleavage.

\subsubsection{Cyanogen bromide cleavage}

2.2.2.1. Native carboxypeptidase $Y(30 \mathrm{mg})$ was dissolved in $2 \mathrm{ml}$ of $70 \%$ formic acid, and the solution purged with a stream of $\mathrm{N}_{2}$ for 10 minutes. Cyanogen bromide $(30 \mathrm{mg}, 1 \mathrm{mg} \mathrm{CNBr}$ per $\mathrm{mg}$ protein) was added, the solution was again purged for 1 minute with $\mathrm{N}_{2}$ and the reaction vessel sealed and stored in the dark for 24 hours. Subsequently, $\mathrm{N}_{2}$ was bubbled 
through the solution for three hours, and then the reaction mixture was chromatographed on Biogel P30.

2.2.2.2. Monoalkylated DIP-CPD-Y was dissolved in $10 \mathrm{ml}$ of $70 \%$ formic acid. The procedure followed was essentially identical to that described above except that the reaction was stopped after 36 hours. Then a small aliquot was removed for sequence analysis. The remaining $4.9 \mu$ moles, as judged by amino acid analysis, was divided into five portions and stored frozen at $-20^{\circ} \mathrm{C}$ until each was subjected to chromatography on Biogel P60 $(2.5 \times 100 \mathrm{~cm})$ using $30 \%$ acetic acid as eluant.

\subsubsection{Chromatographic separation of peptides}

The initial separation of all peptide fragments described in the present report was made by gel permeation chromatography on either Biogel P60 or P30, equilibrated and eluted with $30 \%$ acetic acid. All chromatographic runs were made at room temperature and were continuously monitored at $254 \mathrm{~nm}$ using an LKB Uvicord UV-monitor. After a run was terminated, all fractions were measured at $280 \mathrm{~nm}$ on a Beckman 25 spectrophotometer and the various peak fractions pooled. Non absorbing materials in fractions between peaks were pooled for amino acid analysis. Yields for the total applied material compared to that recovered were determined by amino acid analysis.

Representative samples from each pool were also analyzed by automatic EDMAN degradation as a means of checking the purity and number of fragments present.

In the case of cyanogen bromide cleavage of CM-DIP-CPD-Y peaks eluting at the same volume for the five separations were combined prior to rechromatography and/or reduction of the disulphide bridges.

\subsubsection{Reduction and alkylation}

Reduction of the disulphide bridges in carboxypeptidase $\mathrm{Y}$ was accomplished after $\mathrm{CNBr}$ cleavage and the initial chromatography step. From the amino acid analyses obtained for each peptide pool, the content of cystine could be estimated. The reduction was then made with dithiothreitol in 6 m-guanidine at $\mathrm{pH} \quad 8.6$.
Typically, peptide approx. $1 \mu$ mole was dissolved in $0.1 \mathrm{M}$-Tris- $\mathrm{HCl}$ buffer, $\mathrm{pH} \mathrm{8.6,} \mathrm{containing} 6$ M-guanidine hydrochloride. The solution was purged with $\mathrm{N}_{2}$ for 10 minutes, followed by addition of dithiothreitol (10 fold molar excess over disulphide). The solution was then sealed under $\mathrm{N}_{2}$ and left 16 hours in the dark at room temperature after which the $\mathrm{pH}$ was lowered to 7.5 and $5 \mu \mathrm{l} 4$-vinylpyridine added per $\mu$ mole total sulphydryl. After one hour at room temperature the reduced alkylated peptides were freed of reactants and salts by chromatography on Biogel P6 $(2.0 \times 50 \mathrm{~cm})$ eluted with $30 \%$ acetic acid. The protein peak was pooled and lyophilized prior to amino acid analysis and subsequent sequence analysis or rechromatography on Biogel P30 or P60.

\subsubsection{Amino acid analysis}

Hydrolysis of protein or peptides was performed for 24 hours at $110^{\circ} \mathrm{C}$ in $5.7 \mathrm{M}-\mathrm{HCl}$ in vacuo. Analyses were performed on a Durrum model 500 amino acid analyzer and are uncorrected for partial destruction of hydroxyamino acids as well as for incomplete release of valine and isoleucine bonds. Half-cystines in peptides were determined as pyridylethylcysteine.

\subsubsection{Amino acid sequence determination}

Automated sequence analysis was performed using a Beckman $890 \mathrm{C}$ sequencer as originally described by EDMAN and BEGG (7). The use of THEED as coupling buffer (2) and other modifications have been described (16). In several cases Polybrene was added to the cup prior to or with the sample $(16,27)$. For shorter peptides the Polybrene was run with the dipeptide glycyl-alanine for two cycles prior to introduction of the sample to the cup (13). For longer peptides the Polybrene was added together with the sample and sequencing begun immediately. Identification of the resulting PTH-amino acids was made by HPLC as described by SVENDSEN et al. (26). Additional information was obtained by TLC as described by KULBE (18) or back hydrolyses to the parent amino acids (21). 


\subsubsection{Carbohydrate analysis}

Determination of carbohydrate was made by amino acid analysis (1) for amino sugars like glucosamine and by the phenol-sulphuric acid method for hexoses using glucose as standard (5).

\subsubsection{Acetylation and restricted trypsin cleavage}

In order to restrict tryptic cleavage to only arginine, selected $\mathrm{CNBr}$-peptides were treated with acetic anhydride to irreversibly block the $\mathrm{N}$ terminal and the $\varepsilon$-amino groups of lysyl side chains. Typically, peptide (100 nmoles) was dissolved in $0.050 \mathrm{M}-\mathrm{N}$-ethylmorpholine acetate buffer, $\mathrm{pH} 8.0$ and treated with acetic anhydride $(0.1 \mathrm{ml})$ in aliquots of $0.010 \mathrm{ml}$, maintaining the $\mathrm{pH}$ at 8.0 by manual additions of $0.1 \mathrm{M}-\mathrm{N}$ ethylmorpholine. Twenty minutes after the last addition of reagent the $\mathrm{pH}$ of the solution was lowered to 3.0 by addition of $20 \%$ acetic acid, and one hour later freeze-dried.

The peptide was subsequently taken up in $0.050 \mathrm{~m}-\mathrm{N}$-ethylmorpholine acetate, $\mathrm{pH} 8.0$, the $\mathrm{pH}$ readjusted to 8.0 , where necessary, and trypsin added at a substrate:enzyme ratio of 100:1. The reaction was allowed to proceed for 4 hours at $37^{\circ} \mathrm{C}$, the $\mathrm{pH}$ being continuously maintained between 7.8 and 8.2 by addition of $0.1 \mathrm{M}-\mathrm{N}$-ethylmorpholine. The reaction was terminated by addition of acetic acid to $\mathrm{pH} 2.5$, and subsequent lyophilization.

\subsubsection{Subdigestion with A.mellea protease and S.aureus $V 8$ protease}

One of the peptides, CNBr I-II was cleaved first with the lysine specific protease from A.mellea (20). The peptide 75 nmoles (approx. 1 $\mathrm{mg}$ ) was dissolved in $200 \mu \mathrm{l} \mathrm{of} 0.1 \mathrm{~m}-\mathrm{NH}_{4} \mathrm{HCO}_{3}$, $\mathrm{pH} 8.3$ to which the enzyme $(20 \mu \mathrm{g}$ in $40 \mu \mathrm{l}$ buffer) was added and the reaction allowed to proceed for 18 hours at $38^{\circ} \mathrm{C}$. The digestion mixture was then chromatographed on a column of Biogel P10 $(0.9 \times 100 \mathrm{~cm})$ equilibrated and eluted with $0.1 \mathrm{~m}-\mathrm{NH}_{4} \mathrm{HCO}_{3}$. Absorbance was monitored at $254 \mathrm{~nm}$ with the Uvicord and measured afterwards at $230 \mathrm{~nm}$ on a Beckman Spectrophotometer. Pooled fractions were subjected to amino acid analysis and subsequently peak 3 was selected for automated EDMAN degradation.
The same peak, CNBr I-II-M3, was also subjected to cleavage with $\mathrm{S}$.aureus protease in an attempt to obtain the $\mathrm{C}$-terminal peptide. The peptide $(270 \mu \mathrm{g}, 50 \mathrm{nmoles})$ was dissolved in $500 \mu \mathrm{l} 0.1 \mathrm{MNH}_{4} \mathrm{HCO}_{3}, \mathrm{pH} 7.8$, to which $20 \mu \mathrm{g}$ protease was added (12). After 10 hours at $38^{\circ} \mathrm{C}$, the digest was chromatographed on a Sephadex G.25 (sf) column $(0.9 \times 115 \mathrm{~cm})$ equilibrated and eluted with $0.1 \mathrm{~m}-\mathrm{NH}_{4} \mathrm{HCO}_{3}$. The resulting separation was monitored and treated as described above.

\subsubsection{Tryptophan cleavage}

Cleavage at tryptophan according to FONTANA using dimethylsulphoxide/ $\mathrm{HCl} / \mathrm{HBr}$ (24) was made on the peptide $\mathrm{CNBr}$ II. The peptide (120 nmoles) was dissolved in a mixture of glacial acetic acid $(600 \mu \mathrm{l}) \quad 12 \mathrm{M}-\mathrm{HCl}(300 \mu \mathrm{l})$, dimethylsulphoxide $(3 \mu \mathrm{l})$ and phenol $(20 \mathrm{mg})$. After $30 \mathrm{~min}, 48 \% \mathrm{HBr}(120 \mu \mathrm{l})$ and dimethylsulphoxide $(3 \mu \mathrm{l})$ were added, and the reaction allowed to proceed an additional $30 \mathrm{~min}$, after which $2 \mathrm{ml}$ of $30 \%$ acetic acid were added. After 6 hours the mixture was diluted to $50 \mathrm{ml}$ with water and lyophilized. The resulting peptides were purified by chromatography on a column of Sephadex G-25 (sf) as described above.

\subsubsection{Peptide nomenclature}

Peptides are named from the order of their elution from gel permeation chromatography. The nomenclature is based on the elution profile from the Biogel P30 chromatography of the cyanogen bromide digest of native carboxypeptidase $\mathrm{Y}$. The initial chromatography of $\mathrm{CNBr}$ peptides obtained from native CPD. $Y$ yielded four peaks and are numbered $\mathrm{CNBr} \mathrm{I} \rightarrow \mathrm{IV}$, and peptides separated from these pools then become CNBr I-I, CNBr I-II, etc. Peptides recovered from the cyanogen bromide cleavage of $\mathrm{CM}$ DIP-carboxypeptidase are named after the corresponding peptide from the cleavage on the native enzyme. However, in the case of non-specific cleavage products the peptides are named $\mathrm{CNBr}$ $\mathrm{W}_{\mathrm{I}} \rightarrow \mathrm{W}_{\text {III }}$ where the cleavage occurred after tryptophan, $\mathrm{CNBr}-\mathrm{D}_{1}$ when cleaved between aspartic acid and proline, and $\mathrm{CNBr}-\mathrm{Y}_{I}$ when cleavage after tyrosine.

Peptides recovered after subdigestion by en- 
zymes are identified by their parent peptide e.g. $\mathrm{CNBr}$ I-II followed by the enzyme and peak number e.g. CNBr I-II-M3 for A.mellea on $\mathrm{CNBr}$ I-II. In the case of peptides acetylated prior to digestion by trypsin, the peptide becomes Ac-CNBr $W_{I}-T$. Peptides from S.aureus V8 protease digest have the prefix SP followed by peak number.

\section{RESULTS}

\subsection{Amino-terminal sequence analysis of na- tive carboxypeptidase $Y$}

Initially, carboxypeptidase $Y$ was sequenced after treatment with DFP, iodoacetic acid, reduction and alkylation of the disulphide bridges (see 2.2.1 and 2.2.3). However, two attempts to sequence 150 nanomoles of this material allowed identification of only the first 33 steps although the repetitive yield was $95 \%$ up to step 30 .

In later experiments automated EDMAN degradation was done on the native enzyme in the presence of Polybrene and the unambiguous identification of 43 of the first 44 residues was obtained using only 21 nmoles for sequencing, but now with a repetitive yield of $96 \%$ through 40 steps. The sequence which began Lys-Ile-Lys also provided a six residue overlap with tryptic peptide T 1 (Table II and ref. 26). The failure to identify residue 13 will be discussed later.

\subsection{Amino-terminal analysis of $\mathrm{CNBr}$-peptide mixture derived from CPD-Y}

Analysis of the five first steps of EDMAN degradation made on a digest of native CPD-Y provided a maximum of six PTH-amino acids in any one step suggesting that the cleavage was restricted to the methionine residues.

Five steps of automated EDMAN degradation were also performed on the $\mathrm{CNBr}$-cleavage mixture of CM-DIP-CPD-Y prior to chromatography (see 2.2.2). The PTH-amino acids found in these five steps suggested that there was a minimum of ten peptides at least four of which were either short and/or very hydrophobic and that cleavage occurred at residues other than methionine.

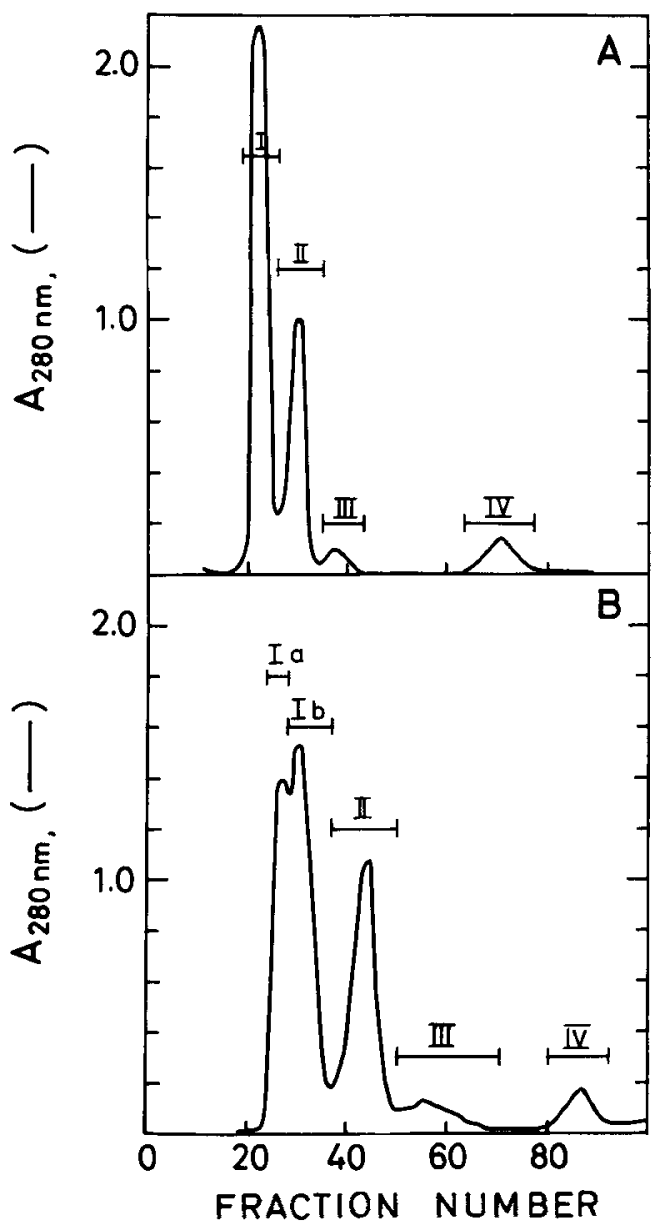

Figure 1. A. Chromatography of cyanogen bromide peptides from native carboxypeptidase $\mathrm{Y}$ on a $2 \times 80$ $\mathrm{cm}$ column of Biogel P30, equilibrated with $30 \%$ acetic acid. The column was eluted at a flow rate of $30 \mathrm{ml} \cdot$ hour $^{-1}$ and fractions of $2.6 \mathrm{ml}$ were collected. Pooled fractions are indicated by horizontal bars.

B. Chromatography of an aliquot of cyanogen bromide cleavage mixture from CM-DIP-carboxypeptidase $Y$ on a $2.0 \times 100 \mathrm{~cm}$ column of Biogel P60, equilibrated with $30 \%$ acetic acid. The flow rate was $30 \mathrm{ml} \cdot$ hour $^{-1}$ and fractions of $2.5 \mathrm{ml}$ were collected. Pooled fractions are indicated by horizontal bars.

\subsection{Isolation of cyanogen bromide fragments}

The elution pattern of the $\mathrm{CNBr}$-peptides obtained from native CPD-Y on Biogel P30 is shown in Figure 1 A. In this digest only four Nterminal residues were identified in the sequencer in step I. As can be seen, initial chromato- 
graphy on Biogel P30 gave rise to four distinct fractions which were pooled as $\mathrm{CNBr} I \rightarrow I V$. Of these one large peptide, $\mathrm{CNBr}$ II, and one small peptide, $\mathrm{CNBr}$ IV, were found to be free of contaminants in the former case by gel electrophoresis (30) and sequence analysis and, in the latter case, only by sequence analysis. $\mathrm{CNBr}$ III was found to contain two peptides which could be separated by repeated gel permeation chromatography or by high performance liquid chromatography using a reverse phase column. $\mathrm{CNBr}$ I was found to be composed of several peptides including the amino-terminal fragment of the enzyme and several minor sequences beginning with proline along with a sequence beginning with a glutamic acid seen in the cyanogen bromide mixture. Repeated gel chromatography failed to provide a separation of the N-terminal peptide and the peptide beginning with glutamic acid. However, upon reduction and pyridylethylation of $\mathrm{CNBr} \mathrm{I}$, a peptide $\mathrm{CNBr}$ I-II (that beginning with glutamic acid) could be recovered in a homogeneous form after rechromatography on Biogel P30. CNBr I-I was still not homogeneous, with increasing amounts of proline appearing in step 1 upon sequencing when further rechromatographed.

Since the initial CNBr-cleavage done on CMDIP-CPD-Y gave rise to many more peptides than expected and suggested cleavage at residues other than methionine the separation of these became quite complicated. In Figure $1 \mathrm{~B}$ is shown the initial chromatography of this peptide mixture on Biogel P60. A recovery of $98 \%$ was obtained based on amino acid analysis of the sample applied and the resulting peptide peaks.

While the $\mathrm{N}$-terminal residues discussed in the previous section were also found here, many other peptides were formed that complicated the identification and separation. Several of the peptides, ultimately recovered in a pure state, were part of the expected cyanogen bromide fragments. These will be discussed one by one later; the expected peptides retain the nomenclature from above, and all but the $\mathrm{N}$-terminal $\mathrm{CNBr}$-fragment were recovered in amounts near $100 \%$ for $\mathrm{CNBr}$ III-I, III-II, and IV and about $40 \%$ for $\mathrm{CNBr}$ I-II and $\mathrm{CNBr}$ II.

\subsection{Amino acid composition and amino-termi- nal sequence of purified $\mathrm{CNBr}$ peptides}

$\mathrm{CNBr}$ II, initially generated by cyanogen bromide cleavage on native carboxypeptidase $\mathrm{Y}$, was found by amino acid analysis to consist of approximately 80 amino acid residues and to contain glucosamine, homoserine and its lactone and no cystine (Table I). Subsequent reduction and pyridylethylation failed to alter the amino acid composition of the peptide with the exception of a slight increase in lysine (possibly pyridylethyl-cysteine) suggesting the presence of the single sulphydryl group in this peptide. The amino acid sequence determined for this peptide began Lys-Pro-Tyr (Table II) and, with the exception of residue 28 , the unambiguous identification of the first 47 residues was possible, with a tentative sequence presented to residue 53. Two sequencer runs with 150 nanomoles each were accomplished with the repetitive yield approximately $95 \%$ through step 40 in both cases.

$\mathrm{CNBr}$ I-II, recovered from Biogel P30 chromatography in a pure form after reduction and alkytation of $\mathrm{CNBr}$ I, was found by amino acid analysis to contain the majority of cystine (determined as pyridylethyl cysteine) in the enzyme and about 1 residue of homoserine and its homoserine lactone (Table I). Its amino acid composition and elution volume from Biogel P30 suggested that the peptide contained approximately 100 residues and at least four arginines. Automated EDMAN degradation provided the amino acid sequence up to and including residue 46 with no identification possible at positions 40 and 43. Two sequencer runs were made using 150 and 50 nanomoles, respectively, with the repetitive yield over $94 \%$ in both cases (Table II).

$\mathrm{CNBr}$ III was after repeated chromatography separated into two components. The first, $\mathrm{CNBr}$ III-I, was found to contain approximately 20 residues, one disulphide bridge and homoserine and its lactone (Table I). One attempt to sequence this peptide after reduction and alkylation resulted in identification of the first three residues: Ala-Cys-Gly and thus identified it as a peptide located in and sequenced as part of tryptic peptide T 3-6 (26). CNBr III-II was not submitted to sequence analysis as it was located in the C-terminal tryptic peptide $\mathrm{T}$ 5-1 along 
Table I

Amino acid composition of CPD-Ya and its cyanogen bromide peptides ${ }^{b}$

\begin{tabular}{|c|c|c|c|c|c|c|c|}
\hline Amino acid & CPD-Y & CNBr I-II & $\mathrm{CNBr}$ II & $\begin{array}{c}\mathrm{CNBr} \\
\text { III-I }\end{array}$ & $\begin{array}{l}\text { CNBr } \\
\text { III-II }\end{array}$ & $\underset{\text { IV }}{\mathrm{CNBr}}$ & $\underset{\mathrm{I}-\mathrm{I}}{\mathrm{CNBr}}$ \\
\hline Aspartic acid & $65.1(65)$ & $18.6(19) \mathrm{c}$ & $11.9(12)^{c}$ & & $2.1(2) \mathrm{c}$ & $1.9(2)^{\mathrm{c}}$ & 30 \\
\hline Threonine & $18.3(18)$ & $3.3(3)$ & $5.7(7)$ & & & 0.2 & 7.6 \\
\hline Serine & $29.7(30)$ & $5.9(6)$ & $3.2(3)$ & $2.9(3)^{\mathrm{c}}$ & $1.0(1)$ & $1.0(1)$ & 13.5 \\
\hline Glutamic acid & $40.4(40)$ & $12.6(13)^{d}$ & $7.0(6)^{d}$ & $4.5^{\mathrm{d}}(4)$ & $1.1^{d}(1)$ & $1.4(1)$ & 22.0 \\
\hline Proline & $24.7(25)$ & $4.8(3)$ & $3.4(3)$ & $2.0(2)$ & $1.8(2)$ & 0.5 & 11.1 \\
\hline Glycine & $34.2(34)$ & $7.2(6)$ & $5.5(5)$ & $3.1(3)$ & 0.3 & $1.4(1)$ & 16.1 \\
\hline Alanine & $22.3(22)$ & $6.0(6)$ & $6.0(6)$ & $2.0(2)$ & $1.0(1)$ & 0.3 & 9.4 \\
\hline Cystine/2 & $8.9(9)$ & & & & & & \\
\hline Valine & $28.5(29)$ & $6.2(6)$ & $6.4(7)$ & $1.1(1)$ & $1.9(2)$ & $1.2(1)$ & 10.2 \\
\hline Methionine & $5.0(5)$ & (1) & (1) & (1) & (1) & & \\
\hline Isoleucine & $19.8(20)$ & $4.7(5)$ & $3.2(3)$ & & 0.2 & $0.8(1)$ & 8.4 \\
\hline Leucine & $35.6(36)$ & $8.8(8)$ & $7.3(7)$ & $1.0(1)$ & $1.0(1)$ & $1.2(1)$ & 16.0 \\
\hline Tyrosine & $24.9(25)$ & $7.2(7)$ & $4.9(5)$ & & & 0.3 & 11.1 \\
\hline Phenylalanine & $25.2(25)$ & $3.9(3)$ & $4.3(4)$ & & $0.9(1)$ & $1.0(1)$ & 13.3 \\
\hline Histidine & $8.9(9)$ & $1.2(1)$ & $2.8(3)$ & & & $0.8(1)$ & 3.1 \\
\hline Lysine & $17.7(18)$ & $2.5(2)$ & $6.6(7)$ & & & 0.2 & 6.5 \\
\hline Arginine & $9.4(9)$ & $4.1(5)$ & $2.0(2)$ & & & & 4.2 \\
\hline Tryptophan & $10.5(10-11)$ & n.d.e(2) & n.d. (3) & & & n.d. (1) & \\
\hline PE-Cys & & $6.4(7)$ & $0.4(1)$ & $1.9(2)$ & & & 1.1 \\
\hline \multirow{2}{*}{$\begin{array}{l}\text { Homoserine } \\
\text { or lactone }\end{array}$} & & & 0.5 & & & & \\
\hline & & 0.4 & 0.5 & 0.2 & $0.4(0)$ & & 0.3 \\
\hline
\end{tabular}

a Amino acid composition of CPD-Y as determined by J. T. JoHANSEN et al. (15).

b Amino acid composition of peptides expressed as residues/mole based on alanine $=6,6,2$ and 1 for $\mathrm{CNBr}$ III, CNBr II, CNBr III-I and CNBr III-II, respectively, and phenylalanine $=1$ for CNBr IV and leucine $=16$ for CNBr I.

c Amino acid composition of peptides calculated from the sequence.

d Glutamic acid includes some homoserine.

$\mathrm{e}$ n.d. $=$ not determined.

with $\mathrm{CNBr}$ IV. Its amino acid composition, however, is presented in Table I.

$\mathrm{CNBr}$ IV, the C-terminal fragment obtained from carboxypeptidase $Y$, was found to be free of homoserine or its lactone and to contain 11 amino acid residues (Table I). The amino terminal of this peptide was found to be ValAsn-Glu and the sequence could not be further extended, but was determined as part of tryptic fragment T 5-1 (26).

$\mathrm{CNBr}-\mathrm{D}_{1}$, a peptide which was estimated to contain 125 amino acid residues (Table III) contained large amounts of glucosamine but lacked homoserine/homoserine lactone. The peptide was eventually isolated from $\mathrm{CNBr} I-\mathrm{I}$, i.e. material in peak 1 of the cyanogen bromide cleavage of native carboxypeptidase Y, Figure 2, peak 1, after repeated chromatography in $30 \%$ acetic acid. The cleavage which provided this peptide occurred between aspartic acid and proline at position 44 and 45 in the $\mathrm{N}$-terminal region of CPD-Y (Figure 4 in the following paper). The amino-terminal sequence began ProVal-Ile and was determined up to residue 40 (Table IV). The repetitive yield on 100 nanomoles was about $94 \%$ up to residue 38 .

$\mathrm{CNBr}-\mathrm{W}_{\mathrm{I}}$, like $\mathrm{CNBr}-\mathrm{D}_{\mathrm{I}}$ contained large amounts of glucosamine and was composed of approximately 110 amino acid residues. It was recovered from the cleavage of CM-DIP-CPD-Y as the first peptide and probably the largest (after reduction and alkylation of pool CNBr I from that digest) eluting from Biogel P60. The peak also contained the DIP-Ser as indicated by scintillation counting of representative aliquots of each chromatography step. Unfortunately, the sequence could not be extended beyond residue 30 with residue 3 and 29 unidentified, with two 
Table II

Amino acid sequence of cyanogen bromide peptides of CPD-Y

\begin{tabular}{|c|c|}
\hline \multirow[t]{2}{*}{$\mathrm{N}$-term. } & 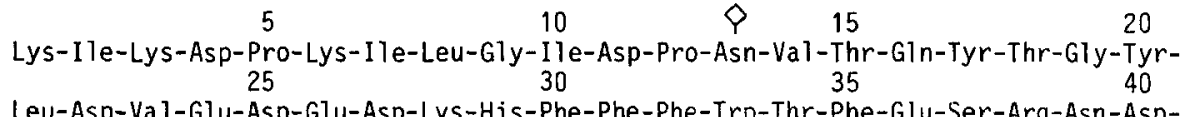 \\
\hline & Pro-Ala-Lys-Asp- \\
\hline
\end{tabular}
CNBr II Lys-Pro-Tyr-His-Thr-Ala-Val-Thr-Asp-Leu-Leu-Asn-Gin-Asp-Leu-Pro-Ile-Leu-Val-Tyr- $25 \quad 8 \quad 30 \quad 35 \quad 40$ Ala-Gly-Asp-Lys-Asp-Phe-I le-Asn-Asn-Thr-Leu-Gly-Asn-Lys-Ala-Trp-Thr-Asp-Val-Leu-

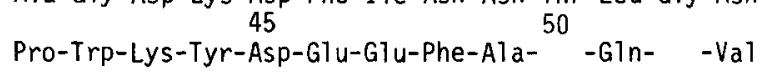
CNBr I-II Glu-Asp-Ser-Leu-Glu-Arg-Cys-Leu-Gly-Leu-Ile-Glu-Ser-Cys-Tyr-Asp-Ser-Gln-Ser-Val- $25 \quad 30 \quad 350$ Trp-Ser-Cys-Val-Pro-Ala-Thr-I Ie-Tyr-Cys-Asn-Asn-Ala-Gln-Leu-Ala-Pro-Tyr-G1n- - 45
Thr-Gly-

CBNr IV Val-Asn-Glu

CNBr III-I Ala-Cys-Gly

$\diamond:$ Indicates an unidentified position which is assumed to be occupied by a
carbohydrate carrying asparagine residue.

sequencer runs on 100 nanomoles, one with and one without Polybrene, the yields being 96 and $94 \%$, respectively. The sequence began Asn-Ser$\mathrm{X}$-Ala and ended abruptly with Ala in step 30 (Table IV).

$\mathrm{CNBr}-\mathrm{W}_{\text {II }}$ was also isolated from the digestion of CM-DIP-CPD-Y and as above only after reduction and alkylation of $\mathrm{CNBr} \mathrm{I}$. As with peptide $\mathrm{CNBr}$ I-II it was found to contain large amounts of pyridylethyl-cysteine and arginine suggesting that it might be a part of $\mathrm{CNBr}$ I-II (Table III). The sequence of this peptide which began Ser-Cys-Val (positions 22-24 in CNBr III) allowed the identification of two arginines (position 40 and 43 in CNBr I-II) which were not identified in tryptic peptides (26). Using 100 nmoles of peptide, the sequence was determined to step 35 (repetitive yield 95\%) and provided an
8 residue overlap with tryptic peptide T 4-7 (Table IV and following paper).

$\mathrm{CNBr}-\mathrm{W}_{\text {III }}$ was found initially as an impurity along with peptide $\mathrm{CNBr}$ II from cyanogen bromide cleavage of CM-DIP-CPD-Y, and again later as a part of the last peak eluting from P60 after reduction and alkylation of $\mathrm{CNBr}$ I from the same digest. The latter material was found to contain $\mathrm{CNBr}-\mathrm{W}_{\mathrm{III}}$ and two other peptides which accounted for $40 \%$ of total. Amino acid analysis provided little information concerning the composition of $\mathrm{CNBr}-\mathrm{W}_{\text {III, }}$, however sequence analysis allowed identification of the first 12 residues and suggested that residue 15 was a tyrosine (Table IV).

$\mathrm{CNBr}_{\mathrm{Y}} \mathrm{Y}_{\mathrm{I}}$ was as $\mathrm{CNBr}-\mathrm{W}_{\mathrm{III}}$ impossible to obtain in a clean enough state to obtain a reliable amino acid composition. It also originated from 
Table III

Amino acid composition of sequenced peptides ${ }^{2}$ obtained from non-specific cyanogen bromide cleavage

\begin{tabular}{|c|c|c|c|}
\hline & CNBr-WI & $\mathrm{CNBr}-\mathrm{W}_{\mathrm{II}}$ & CNBr-DI \\
\hline Asp & 15.8 & 15.0 & 17.3 \\
\hline Thr & 4.4 & 3.6 & 5.2 \\
\hline Ser & 9.0 & 3.4 & 11.0 \\
\hline Glu & 9.7 & 6.2 & 10.0 \\
\hline Pro & 5.5 & 2.7 & 9.2 \\
\hline Gly & 10.0 & 6.2 & 12.7 \\
\hline Ala & 6.0 & 6.0 & 6.0 \\
\hline Val & 7.8 & 5.4 & 8.4 \\
\hline Ile & 4.6 & 4.3 & 5.9 \\
\hline Leu & 9.2 & 6.7 & 11.5 \\
\hline Tyr & 6.7 & 6.6 & 6.7 \\
\hline Phe & 7.8 & 4.4 & 10.7 \\
\hline His & 2.4 & 1.3 & 2.5 \\
\hline Lys & 3.2 & 3.1 & 4.8 \\
\hline Arg & 1.5 & 3.1 & 1.3 \\
\hline $\begin{array}{l}\text { Homoserine } \\
\text { or lactone }\end{array}$ & 0.4 & 0 & 0 \\
\hline
\end{tabular}

a Amino acid composition calculated as residues/ mole based on alanine $=6$.

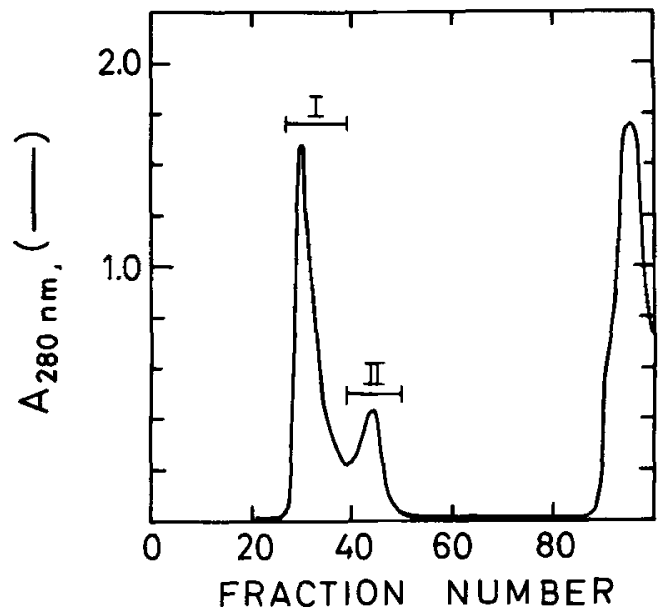

Figure 2. Chromatography of pool CNBr I from Figure 1 A after reduction and pyridylethylation on a Biogel P30 column $(2 \times 95 \mathrm{~cm})$ equilibrated and eluted with $30 \%$ acetic acid.

The flow rate was $30 \mathrm{ml} \cdot$ hour $^{-1}$ and fractions of $2.8 \mathrm{ml}$ were collected. Pooled fractions are indicated by horizontal bars.

\section{Table IV}

\section{Amino acid sequence of peptides generated by non-specific cleavage}

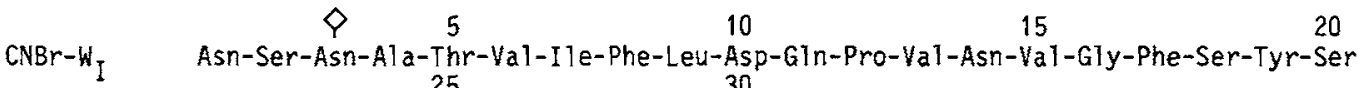

$$
\begin{aligned}
& \text { Gly-Ser-Ser-Gly-Val-Ser-Asn-Thr- -Ala } \\
& \text { CNBr-W II Ser-Cys-Val-Pro-Ala-Thr-Ile-Tyr-Cys-Asn-Asn-Ala-Gln-Leu-Ala-Pro-Tyr-Gln-Arg-Thr- } \\
& \text { Gly-Arg-Asn-Val-Tyr-Asp-I le-Arg-Lys-Asp-Cys-Glu-Gly-Gly-Asn-Leu }
\end{aligned}
$$

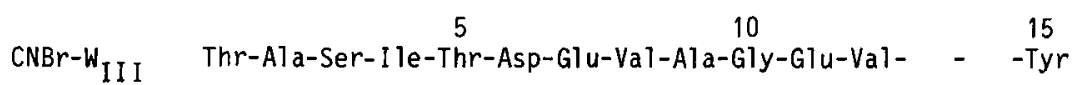

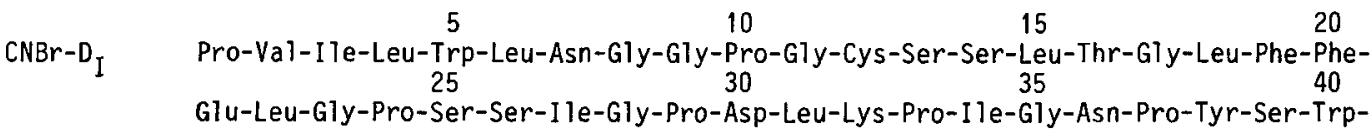

$$
\begin{aligned}
& \text { CNBr-Y I Ala-His-Gly-Tyr-I I le-Pro-VaT-Phe-Ala- }{ }^{10} \text {-Glu-Ile-Leu-Ser-His }
\end{aligned}
$$

$P$ : Indicates an unidentified position which is assumed to be occupied by a carbohydrate carrying asparagine residues. 
CNBr-cleavage of CM-DIP-CPD-Y pool CNBr I after reduction and alkylation, as the major component of three, eluting as a peak just prior to $\mathrm{CNBr}-\mathrm{W}_{\text {III. }}$. The amino acid sequence was followed 15 steps (after which the background became excessive) and began Ala-His-Gly (Table IV).

\subsection{Sequence determination through subdiges- tion of CNBr peptides}

$\mathrm{CNBr}$ I-II was digested with A.mellea protease and after chromatography of the digest on P10 a peptide (peak 3) was obtained which had the amino-terminal sequence Lys-Asp-Cys and contained homoserine and homoserine lactone. Further digestion of this peptide (CNBr I-II-M3) with S.aureus V8 protease provided a peptide CNBr I-II-M3-SP3 which also contained homoserine and its lactone. Sequence analysis of this C-terminal peptide provided a four residue overlap with tryptic peptide $T_{2}(26)$ and thus completed the sequence of $\mathrm{CNBr}$ I-II. The sequence determined for $\mathrm{CNBr}$ I-II-M3-SP3 was: Ser-Cys-Asn-Phe-Asp-Ile-Asn-Arg-AsnPhe-Leu-Phe.

When CNBr II was treated with DMSO/ $\mathrm{HCl} / \mathrm{HBr}$ as described (see 2.2.10) for cleavage at tryptophan a peptide beginning Thr-Ala-Ser was located as part of two peaks from the G-25 chromatography of the digest. In one peak the contaminant peptide was one obtained by cleavage at $\mathrm{Thr}(30)$ in $\mathrm{CNBr}$ II and in the other the contaminant peptide was one beginning with Lys (1). The amino acid sequence in both cases could be followed to step 19 and was Thr-Ala-Ser-IleThr-Asp-Glu-Val-Ala-Gly-Glu-Val-Lys-SerTyr-Lys-His-Phe-Thr.

When either $\mathrm{CNBr}-\mathrm{D}_{\mathrm{I}}$ or $\mathrm{CNBr}-\mathrm{W}_{\mathrm{I}}$ were acetylated and cleaved at arginine with trypsin (see 2.2.8) the new $\mathrm{N}$-terminal peptide began Asn-Phe- X -Leu, connecting both peptides to tryptic peptide T3-6 and placing them both in $\mathrm{CNBr} \mathrm{I}$ in sequential order i.e. $\mathrm{N}$-terminal $\mathrm{CNBr}-\mathrm{D}_{1}-\mathrm{CNBr}_{\mathrm{N}}-\mathrm{W}_{\mathrm{I}}-\mathrm{T} 3-6$.

Digestion of pool CNBr I (Figure 1, peak 1B) after reduction and alkylation and separation of $\mathrm{CNBr}$ I-II with trypsin as described in 2.2.8 resulted in a peptide mixture which could not be adequately separated on Biogel or Sephadex. Therefore an attempt was made to achieve separation on ConA Sepharose (6) by binding any glycopeptides and eluting any non-sugar containing peptides. One peptide was not bound to ConA and was found to contain ${ }^{3} \mathrm{H}$-DIP-Ser by scintillation counting and its retention time as the PTH-derivative on HPLC. The sequence was determined to be Gly-Gln-Asp-Phe-His-Ile-AlaGly-Glu-Š̉er-Tyr-Ala-His-Gly-Tyr.

\section{DISCUSSION}

The amino acid composition of CPD-Y from this laboratory (Table I) has been reported previously as have those from several other groups $(10,15,17)$. The enzyme contains approx. 430 amino acids, including one sulphydryl group, either four or five disulphide bridges and five methionine residues. The content of carbohydrate in the enzyme from this laboratory was approx. $23 \%$ and evidence has been presented by other groups $(9,28)$ for the attachment of this carbohydrate to four asparagine residues. Data will be presented in the following report to support this hypothesis.

Cyanogen bromide cleavage of the native enzyme and separation of the resulting peptide mixture on Biogel P30 allowed the isolation of five of the six peptides expected by cleavage at methionine. The amino acid compositions of the five pure peptides account for approximately 230 residues suggesting that the remaining fragment contains 200 residues (Table I).

The amino acid sequences determined for the $\mathrm{N}$-terminal of the enzyme and the five cyanogen bromide peptides are presented in Table II. The largest fragment, nominally $\mathrm{CNBr} \mathrm{I}$, was not located as a homogeneous entity and sequence analysis of the pool CNBr I (Figure 2) after reduction and alkylation revealed the presence of the N-terminal sequence of the enzyme and several sequences beginning with proline. Ultimately a peptide, $\mathrm{CNBr}-\mathrm{D}_{\mathrm{I}}$, which contained 125 amino acids and no homoserine was isolated from the pool CNBr I. From the N-terminal sequence of the native enzyme and of tryptic peptide $T_{1}$ we were able to confirm an aspartic acid-proline bond cleavage due to the acidic nature of the chromatography eluant, a phenomenon which is well documented $(19,23)$.

Cyanogen bromide cleavage of the CM-DIPenzyme also permitted the isolation of five of the 
six expected peptides; however, the yields of some of these were dramatically reduced (in case of the larger peptides CNBr I-II and $\mathrm{CNBr}$ II, the yields dropped from $80 \%$ each for $\mathrm{CNBr}$ cleavage on the native enzyme to $40 \%$ and $35 \%$ respectively, here). The peptides obtained from the CNBr cleavage of CM-DIP-CPD-Y were a result of peptide bond cleavage after methionine, tryptophan and tyrosine. CNBr I-II from the $\mathrm{CNBr}$ cleavage of the native enzyme (Figure 2, peak 2) was a clean peptide; however, in the $\mathrm{CNBr}$ cleavage of CM-DIP-CPD-Y, the peptide was contaminated by a second peptide found to be contained in the fragment $\mathrm{CNBr}$ I-II. The new sequence $\left(\mathrm{CNBr}-\mathrm{W}_{\text {II }}\right.$ in Table IV) began at Ser(22) in CNBr I-II and after purification on Biogel P30 permitted the sequence of CNBr I-II to be extended to residue 57 . Similarly, preliminary sequence analysis of the pool II (Figure 1B), found to be clean in $\mathrm{CNBr}$ cleavage of the native enzyme, revealed the presence of a peptide (CNBr-W beginning Thr-Ala-Ser-Ile-Thr. Repeated attempts to isolate the peptide $\mathrm{CNBr}-\mathrm{W}_{\mathrm{III}}$ in a pure form failed to remove small amounts of the parent peptide $\mathrm{CNBr}$ II and another peptide with a sequence beginning Thr-Asp-Val. Both these peptides were contained in CNBr II and were the result of cleavage after tryptophan in the parent peptide. In the case of pool CNBr Ia (Figure 1B), a preliminary sequence analysis revealed the presence of the expected $\mathrm{N}$-terminal sequence and $\mathrm{CNBr}$ I-II sequence along with two other sequences in minor amounts: Asn-Ser- $\mathrm{X}$-Ala and Pro-Ala-Lys. After reduction and alkylation of pool $\mathrm{CNBr}$ la (Figure IB) and repeated chromatography on Biogel P60, the peptide $\mathrm{CNBr}^{-W_{I}}$ (Table IV) beginning Asn-Ser- X -Ala was isolated. From the overlap provided by A.mellea peptide 1 (AM-1 in ref. 26) the cleavage was found to be after $\operatorname{Trp}(84)$. Also recovered after the $\mathrm{CNBr}$ cleavage of CM-DIPCPD-Y was the peptide $\mathrm{CNBr}-\mathrm{Y}_{\mathrm{I}}$ which resulted from cleavage after tyrosine. This peptide was contained in the ${ }^{3} \mathrm{H}$-serine peptide isolated after chromatography on ConA Sepharose of trypsin treated pool CNBr I-Ib (Figure 1B). The nonspecific cleavage at the carboxyl side of tryptophan peptide bonds by cyanogen bromide has been reported previously $(3,22)$ and the apparent increase in yield of some of the peptides (e.g.
$\mathrm{CNBr}-\mathrm{W}_{1}$, approx. doubled in quantity during the purification procedure) in the presence of acetic acid has been discussed by FonTANA (8) for the DMSO/halogen acid cleavage method for tryptophan (24). However, one is also reminded of the tyrosine cleavage seen by W ACHTER and WerhahN (29) and Fontana (8) when iodosobenzoic acid is used for tryptophan cleavage. We are unable to ascertain why these non-specific cleavage reactions occur but would suggest that either the cyanogen bromide contained some impurity or that the reaction time was excessively long, allowing oxidative degradation to occur at tryptophan and tyrosine. These cleavages, although unexpected, were very convenient in that they enabled the sequence of several peptides to be extended and in association with those peptides described in the following paper enabled the complete sequence of 5 of the $6 \mathrm{CNBr}$ peptides to be determined.

In contrast to the sequences presented briefly in the Results section, the Table III and IV identify several amino acid residues as Asn(carbohydrate). From the sequence determined these positions were empty but in all cases were followed two positions after by a threonine residue and the peptide sequenced contained carbohydrate, both by the amino acid analysis method for glucosamine and the phenol-sulphuric acid method for hexoses. The tripeptide sequence Asn(carbohydrate)- X -Ser/Thr is well documented (14) and a more comprehensive discussion is presented in the following paper.

One of the major problems encountered in the $\mathrm{CNBr}$ cleavage of CM-DIP-carboxypeptidase $\mathrm{Y}$ was the number of peptides generated. Nevertheless, the ${ }^{3} \mathrm{H}$-phosphoserine was located in a tryptic peptide obtained from pool $\mathrm{CNBr} \mathrm{Ib}$ (Figure 1B). However, in the case of the ${ }^{14} \mathrm{C}$ carboxymethyl-cysteine containing peptide, all attempts to locate the correct peptide failed. Radioactivity as ${ }^{14} \mathrm{C}$ was located in several peptides, suggesting that reaction had taken place at several amino acid residues. Whether the carboxymethylation occurred either at more than one cysteine due to disulphide rearrangement or at lysine or histidine due to the denaturing conditions of 6 M-guanidine has not been determined. We are looking for the location of the single sulphydryl group while we determine the location of the remaining four disulphide 
bridges (one has been located in CNBr III-I).

The alignment of the peptides sequenced is presented in the following paper along with the criteria used for the tentative sequence. With the sequence data obtained from the peptides in the present report and in the following paper 416 of the approx. 430 amino acid residues in carboxypeptidase $Y$ have been placed in their sequential order.

\section{ACKNOWLEDGEMENTS}

The authors wish to express their appreciation to Professor Martin OtTESEN for his continued encouragement and helpful discussions during the course of this work. The excellent technical assistance of LONE Sørensen and BODIL CORNELIUSSEN is gratefully acknowledged. BRIAN MARTIN thanks the board of the Carlsberg Laboratory for financial support.

\section{REFERENCES}

1. BeELey, J. G.: Location of the carbohydrate groups of ovomucoid. Biochem. J. 159, 335345 (1976)

2. BeGG, G. S. \& F. J. MoRgan: A non-volatile buffer with improved performance in automated protein sequencing. FEBS Lett. 65, 243-245 (1976)

3. Blumenthal, K. M., K. Moon \& E. L. Smith: Nicotinamide adenine dinucleotide phosphatespecific glutamate dehydrogenase of Neurospora. II. Sequences of the cyanogen bromide peptides; the complete sequence of the enzyme. J. Biol. Chem. 250, 3644-3654 (1975)

4. Doi, E., R. Hayashi \& T. Hata: Purification of yeast proteinases. Agr. Biol. Chem. 31, 160-169 (1967)

5 Dubois, M., K. A. Gilles, J. K. Hamilton, P. A. Rebers \& F. Smith: Colorimetric method for determination of sugars and related substances. Anal. Chem. 28, 350-356 (1956)

6. Dufau, M. L., T. Tsurumara \& K. J. Catt: Interaction of glycoprotein hormones with agarose-concanavalin A. Biochim. Biophys. Acta 278, 281-292 (1972)

7. Edman, P. \& G. BeGg: A protein sequenator. Eur. J. Biochem. 1, 80-91 (1967)

8. Fontana, A., D. Dalzoppo, C. Grand \& M. Zambonin: Chemical cleavage of tryptophanyl and tyrosyl peptide bonds via oxidative halogenation mediated by o-iodosobenzoic acid. Biochemistry 20, 6997-7004 (1981)
9. Hasilik, A. \& W. TANner: Carbohydrate moiety of carboxypeptidase $\mathrm{Y}$ and perturbation of its biosynthesis. Eur. J. Biochem. 91, 567-575 (1978)

10. Hayashi, R., S. Moore \& W. H. Stein: Carboxypeptidase from yeast. Large scale preparation and the application to $\mathrm{COOH}$-terminal analysis of peptides and proteins. J. Biol. Chem. 248, 2296-2302 (1973)

11. Hayashi, R., S. Moore \& W. H. Stein: Serine at the active centre of yeast carboxypeptidase. J. Biol. Chem. 248, 8366-8369 (1973)

12. Houmard, J. \& G. R. Drapeau: Staphylococcal protease. A proteolytic enzyme specific for glutamoyl bonds. Proc. Natl. Acad. Sci. USA 69, 3506-3509 (1972)

13. Hunkapiller, M. W. \& L. E. Hood: Direct microsequence analysis of polypeptides using an improved sequenator, a non-protein carrier (Polybrene), and high pressure liquid chromatography. Biochemistry 17, 2124-2133 (1978)

14. Hunt, L. T. \& M. O. DayhofF: The occurrence in proteins of the tripeptides Asn- X -Ser and Asn- X -Thr and of bound carbohydrate. Biochem. Biophys. Res. Commun. 39, 757-765 (1970)

15. Johansen, J. T., K. Breddam \& M. Ottesen: Isolation of carboxypeptidase $\mathrm{Y}$ by affinity chromatography. Carlsberg Res. Commun. 41, 1-15 (1976)

16. Johansen, J. T., C. Overballe-Petersen, B. Martin, V. Hasemann \& I. Svendsen: The complete amino acid sequence of copper, zinc superoxide dismutase from Saccharomyces cerevisiae. Carlsberg Res. Commun. 44, 201-217 (1979)

17. Kuhn, R. W., K. A. Walsh \& H. Neurath: Isolation and partial characterization of an acid carboxypeptidase from yeast. Biochemistry 13, 3871-3877 (1974)

18. KULBE, K. D.: Micropolyamide thin-layer chromatography of phenylthiohydantoin amino acids (PTH) at the subnanomolar level. A rapid microtechnique for simultaneous multisample identification after automated Edman degradation. Anal. Biochem. 59, 564-573 (1974)

19. Landon, M.: Cleavage at aspartyl-prolyl bonds. Methods in Enzymol. 47, 145-149 (1977)

20. Lewis, W. G., J. M. Basford \& P. L. Walton: Specificity and inhibition studies of Armillaria mellea protease. Biochim. Biophys. Acta 522, $551-560$ (1978)

21. MENDEZ, E. \& C. Y. LAI: Regeneration of amino acids from thiazolinones formed in the Edman degradation. Anal. Biochem. 68, 47-53 (1975) 
22. Ozols, J. \& C. Gerard: Cleavage of tryptophanyl peptide bonds in cytochrome $b_{5}$ by cyanogen bromide. J. Biol. Chem. 252, 5986-5989 (1977)

23. Piszkifwicz, D., M. Landon \& E. L. Smith: Anomalous cleavage of aspartyl-proline peptide bonds during amino acid sequence determinations. Biochem. Biophys. Res. Commun. 40, 1173-1178(1970)

24. Savige, W. E. \& A. Fontana: Cleavage of the tryptophanyl peptide bond by dimethyl sulfoxide-hydrobromic acid. Methods Enzymol. 47, 459-469 (1977)

25. Svendsen, I., B. Martin \& I. Jonassen: Characteristics of Hiproly barley III. Amino acid sequences of two lysine rich proteins. Carlsberg Res. Commun. 45, 79-85 (1980)

26. Svendeen, I., B. Martin, T. Viswanatha \& J. T. JoHANSEN: Amino acid sequence of carboxypeptidase Y. II. Peptides from enzymatic cleavages. Carlsberg Res. Commun. 47, 15-27 (1982) (1982)

27. TARR, G. E., J. G. Beecher, M. Bell \& D. J. McKeaN: Polyquarternary amines prevent pep- tide loss from sequenators. Anal. Biochem. 84, 622-627 (1978)

28. Trumble, R. B. \& F. Maley: The use of endo- $\beta$ $\mathrm{N}$-acetyl-glucosaminidase $\mathrm{H}$ in characterizing the structure and function of glycoproteins. Biochem. Biophys. Res. Commun. 78, 935-944 (1977)

29. Wachter; R. \& WerhahN: Cleavage of Trp-, Tyr-, and His-bonds suited for attachment to aminosupports and subsequent Edman degradation. In: Methods in Peptide and Protein Sequence analysis. C. Birr ed., Elsevier/North Holland Biomedical Press, Amsterdam pp. 2133 (1980)

30. Weber, K., J. R. Pringle \& M. Osborn: Measurement of molecular weights by electrophoresis on SDS-acrylamide gel. Methods Enzymol. 26, 3-27 (1972)

31. WidMER, F \& J. T. Johansen: Enzymatic peptide synthesis. Carboxypeptidase Y catalyzed formation of peptide bonds. Carlsberg Res. Commun. 44, 37-46 (1979) 